\title{
The Effectiveness of Using Le Duo Tir Tools in Increasing Petanque Shooting Accuracy
}

\author{
*Muhammad Ridwan Lubis, Andi Gilang Permadi, Ali Muhaimin \\ Sport and Health Education Department, Faculty of Sport Science and Public Health, \\ Universitas Pendidikan Mandalika. Jl. Pemuda No. 59A, Mataram, Indonesia. \\ Postal code: 83125
}

*Corresponding Author e-mail: ridwanloebis@gmail.com

Received: July 2021; Revised: September 2021; Published: December 2021

\begin{abstract}
The problem in this study is that the limitations of special equipment in shooting training cause low accuracy in shooting for NTB petanque athletes. The aim of this study was to determine the effectiveness of using the Le Duo Tir tool in increasing the accuracy of shooting petanque. A quasi-experimental research method was used in this study, which consisted of an experimental group and a control group with a test and post-test research design with non-equivalent control-group design. Data analysis begins with the prerequisite test KormogorovSmirnov Test before conducting the Paired Sample T-Test, homogeneity test for the post-test data of the experimental group and control group, and continued with the Independent Sample T-Test. The results of the Independent Sample T-Test test obtained the value of Sig. (2-tailed) of $0.000<0.05$, it is concluded that there is a difference in the effect of shooting accuracy between the experimental group and the control group, but the use of the Le Duo Tir tool is stated to be more effective in increasing shooting accuracy (mean $=28.90)$ than conventional training $($ mean $=20.40)$.
\end{abstract}

Keywords: Le Duo Tir, shooting petanque

How to Cite: Lubis, M., Permadi, A., \& Muhaimin, A. (2021). The Effectiveness of Using Le Duo Tir Tools in Increasing Petanque Shooting Accuracy. Prisma Sains : Jurnal Pengkajian Ilmu dan Pembelajaran Matematika dan IPA IKIP Mataram, 9(2), 186-192. doi:https://doi.org/10.33394/j-ps.v9i2.4074

https://doi.org/10.33394/j-ps.v9i2.4074

Copyright $\odot$ 2021, Lubis et al This is an open-access article under the CC-BY License.

\section{INTRODUCTION}

Petanque is a form of boules game that aims to deliver an iron ball (boules) as close as possible to a wooden ball (jack), the position of both feet must be in a circle before throwing (Agustina, 2017). Petanque is a sport that requires manipulative movement skills (throwing) and visual object control where the athlete must throw boules to get close to or get rid of points (Samsudin \& Low, 2018). There are several numbers or categories that are competed such as: triple male and female, triple mix, double male and female, double mix, single male and female, and shooting male and female. In the shooting category, line shooting is provided with a distance between the circle (where the athlete will be shooting) and the target iron ball, each 6 meters, 7 meters, 8 meters and 9 meters consisting of 5 stations. The number of points that can be obtained is 0 points, 1 point, 3 points, and 5 points for each shooting done. Athletes are only given the opportunity to shoot once from each distance and station (Hanief \& Purnomo, 2019).

There are 2 basic techniques of petanque sports, the first is pointing, which is a type of throwing an iron ball that aims to approach a wooden ball as a target and closer than an opposing player's iron ball. In doing the pointing technique there are several ways that can be done including roll, soft lob, and full lob. The second type of throw is shooting, which is a type of throw to get rid of the opponent's iron ball from the target's wooden ball (Badaru, 
Hasmyati, et al., 2021). There are several ways to do shooting techniques, including shot on the iron, short on shot and shot on ground (Bustomi et al., 2020).

To become a great player, mastery of technical skills in petanque is an absolute must. As stated by (Wahyudhi et al., 2021) To acquire high technical skills, it must be done with a strict training program, especially athletes who choose to specialize in shooting numbers or categories, because a shooter must have a high level of accuracy in order to get the maximum score with a short on shot. (Lubis \& Permadi, 2020) To win a match, shooting technique skills are the most important part of the petanque game. If in a team, the shooting abilities of the athletes are not qualified, then the team will find it difficult to win the match. Therefore, the training program that is run to master shooting techniques must be really strict because the level of difficulty in doing shooting techniques has a higher level of difficulty when compared to ponting, but that does not mean ignoring the pointing training program. (Khofifah et al., 2021) stated, in training shooting skills, it is necessary to be trained in stages starting from how to perform good and correct, measurable and sustainable movement techniques both in terms of training intensity and training load, so that effective shooting motion automation will be created and reduce errors in shooting techniques carried out (Wahyudhi et al., 2021).

The results of observations from the match that took place during the 2019 Pekan Olahraga Nasional (PRAPON) at the Cendrawasih Sports Center Jakarta, the shooting success rate of West Nusa Tenggara (NTB) petanque athletes was still relatively low. Of the 11 categories contested, the NTB petanque team only won two bronze medals, namely in the double man and shooting woman categories (FOPI, 2019). This is shown in an average match of 20 shooting opportunities, athletes are only able to make 7 shots on target, dengan kata lain (Sutrisna et al., 2018) under certain conditions the decision that must be taken by athletes is to shoot, but tends to choose to do pointing techniques rather than shooting.

This problem was caused by the limitations of special equipment in shooting training during preparation for the 2019 PRAPON event using only conventional equipment, namely the boules challenge and barrier media. This statement is in line with research recommendations which state that the use of equipment that is more varied, efficient and pays attention to comfort and safety can make athletes more leverage in carrying out petanque shooting training model movements (Sutrisna et al., 2018). In supporting achievements other than technical factors, the availability of facilities and infrastructure for achievement development both at the national and regional levels is an important part of the success of coaching sports achievements (Irawan \& Pangesti, 2020).

To overcome these problems, the treatment is carried out in the form of exercises using the Le Duo Tir Obut tool, which is a special tool in the form of a target to train shooting accuracy consisting of 2 boules made of semi-soft stainless steel connected to a stainless steel cable and covered with rubber. produced by the French manufacturer Obut. The use of this tool is more efficient and practical to use in training to improve shooting accuracy, where athletes only focus on how to shoot so that they hit the target (Le Duo Tir Obut) from the closest to the farthest distance from the ideal distance to play in a real petanque game, without rearranging Boules challenge as conventional exercises are often done (Obut, 2021).

Similar studies have been carried out but not specifically the use of the Le Duo Tir Obut tool, including research (Badaru, Rachmat Kasmad, et al., 2021) the effect of accuracy and muscle strength training on pentanque shooting ability, research (Purnomo \& Yendrizal, 2020) the effect of eye-hand coordination, concentration and self-confidence to improve petanque shooting accuracy, research (Putra \& Kurdi, 2020) the effect of direct instruction training on improving shooting skills and petanque pointing.

\section{METHOD}

This type of research is quantitative research using experimental methods (Yusuf, 2017), (Hastjarjo, 2019) dan (Setyanto, 2013). The experimental method used is quasi- 
experimental (Creswell, 2017), which consists of the experimental group (using the Le Duo Tir tool) and the control group (conventional). The quasi-experimental research design used was pre-test and post-test with non-equivalent control-group design (Isnawan, 2020).

\begin{tabular}{llccc|}
\hline & & Pre-test & Treatment & Post-test \\
Experimental Group & $:$ & $\mathrm{O}_{2}$ & $\mathrm{O}$ \\
\hline
\end{tabular}

Gambar 1. Pre-test and post-test with non-equivalent control-group design (Isnawan, 2020)

This study uses the entire population used as research subjects, so this research is referred to as population research with a sampling technique that is total sampling (Arieska, 2018) which amounted to 20 athletes from the NTB petanque team. Pre-test and post-test data collection using the standard instrument of shooting precision petanque by (Souef Gilles, 2015). The division of the experimental and control groups using ordinal pairing. The research data were analyzed by parametric statistics using the SPSS version 23 program, including: research data processing begins with conducting a prerequisite test of data analysis using the Kormogorov-Smirnov Test normality test before conducting the Paired Sample TTest, homogeneity test for each post-test data experimental group and control group, and continued with Independent Sample T-Test.

\section{RESULTS AND DISCUSSION}

The prerequisite test for data analysis used the Kormogorov-Smirnov Test for normality. The basis for making the decision on the normality test uses the Shapiro-Wilk. When compared with the value $\alpha=0.05$. Then the results of the pre-test and post-test of the experimental group obtained the value of Sig. $0.863>0.05$ and Sig. $0.753>0.05$. The results of the pre-test and post-test of the control group obtained a th value of Sig. $0.624>0.05$ and $0.124>0.05$. This means that the research data is normally distributed. In table 1 .

Tabel 1. Tests of Normality

\begin{tabular}{lcc}
\hline \multirow{2}{*}{ Kelompok } & Kolmogorov-Smirnov $^{\mathrm{a}}$ & Shapiro-Wilk $^{\circ}$ \\
\cline { 2 - 3 } & Sig. & Sig. \\
\hline Pre-test Experiment (Le Duo Tir) & $.200^{*}$ & .863 \\
\hline Post-test Experiment (Le Duo Tir) & $.200^{*}$ & .753 \\
\hline Pre-test Control (Conventional) & .108 & .624 \\
\hline Post-test Control (Conventional) & $.200^{*}$ & .102 \\
\hline
\end{tabular}

The requirement for using Paired Sample T-Test is that the data is normally distributed. Based on Pair 1 obtained the value of Sig. (2-tailed) of $0.000<0.05$, which means that there is an effect on the accuracy of shooting results for the pre-test of the experimental group and the post-test of the experimental group. Based on Pair 2, the value of Sig (2-tailed) is 0.000 $<0.05$, which means that there is an effect on the accuracy of shooting results for the control group pre-test and the control group post-test. In table 2.

Tabel 2. Paired Sample Test

\begin{tabular}{llcc}
\hline & & Df & Sig. (2-tailed) \\
\hline Pair 1 & Pretest Experiment - Posttest Experiment & 9 & .000 \\
\hline Pair 2 & Pretest Control - Posttest Control & 9 & .000 \\
\hline
\end{tabular}


Berdasarkan uji homogenitas diperoleh nilai signifikansi (Sig.) Based on Mean adalah sebesar $0.506>0.05$, sehinigga dapat disimpulkan bahwa varians data post-test kelompok eksperimen dan data post-test kelompok kontrol adalah sama atau homogen. Pada tabel 3.

Tabel 3. Test of Homogeneity of Variance

\begin{tabular}{lcccc}
\hline & Levene Statistic & df1 & df2 & Sig. \\
\hline Based on Mean & .461 & 1 & 18 & .506 \\
\hline
\end{tabular}

Based on the homogeneity test, the significance value (Sig.) Based on Mean is $0.506>$ 0.05 , so it can be concluded that the variance of the post-test data of the experimental group and the post-test data of the control group is the same or homogeneous. In table 3.

Tabel 4. Independent Samples Test

\begin{tabular}{lccccc}
\hline & F & Sig. & T & Df & Sig. (2-tailed) \\
\hline Equal variances assumed & .461 & .506 & 5.574 & 18 & .000 \\
\hline
\end{tabular}

To see how big the difference between the post-test results of the experimental group and the post-test of the control group on the statistical results of the independent t-test, where the results of the shooting accuracy of the experimental group obtained a mean value of 28.90 , the results of the shooting accuracy of the control group obtained a mean value of 20 . 40. The mean is greater for the experimental group than for the control group. In table 5.

Tabel 5. Group Statistics

\begin{tabular}{lll}
\hline \multicolumn{1}{c}{ Kelompok } & N & Mean \\
\hline Post-test Experimental Group (Le Duo Tir) & 10 & 28.90 \\
\hline Post-test Control Group (Conventional) & 10 & 20.40 \\
\hline
\end{tabular}

Based on the results of the analysis of research data, it was found that there was an effect of using the Le Duo Tir tool and conventional training on the accuracy of shooting for NTB petanque athletes. However, the use of the Le Duo Tir tool has a greater effect than conventional training on the accuracy of shooting for NTB petanque athletes. In other words, the use of the le duo tir tool is more effective in increasing the shooting accuracy of the NTB petanque athletes than using conventional training. The results of this study are in accordance with what is recommended from the results of studies that have been carried out (Badaru, Hasmyati, et al., 2021) and (Sutrisna et al., 2018) which state that the use of more varied, efficient equipment and pay attention to comfort and safety can make athletes more leverage in doing the movements of the petanque shooting exercise model.

The use of Le Duo Tir was found to be effective in increasing shooting accuracy (mean=28.90). The application of the Le Duo Tir tool in shooting practice emphasizes principles, concentration, coordination and accuracy. In line with the results of this study (Agustina, 2017) stated that a high level of concentration is needed in shooting petanque so as to obtain the maximum value, (Lubis \& Permadi, 2021) a high level of concentration will form good movement coordination so as to create accuracy in shooting petanque, (Nurfatoni \& Hanief, 2020) stated that shooting accuracy is obtained from athletes who have good concentration and movement coordination.

The application of the Le Duo Tir tool in the treatment carried out, the athlete's activity is only concentrated on how to hit the target without rearranging the boules challenge as in conventional training. As stated (Komarudin, 2013) the inability of athletes to concentrate can be caused by disturbing stimuli that come from outside and within the athlete. The application of the Le Duo Tir tool is an effective way to reduce other activities that can interfere with the athlete's concentration, as stated (Jannah, 2017) stimulation from outside or 
from within the athlete can affect the athlete's concentration. (Hutabarat et al., 2017) stated that athletes who have a high level of concentration also have a good level of motion awareness or kinesthetic perception, (Rizal et al., 2020) stated that kinesthetic perception helps athletes know the truth of the movements they are doing so that it has an effect on which greatly increases the shooting accuracy.

The application of the Le Duo Tir tool, athletes shoot from the closest to the farthest distance (the ideal distance to play is from 6 to 10 meters). This condition stimulates athletes to visually measure the distance between the target, arm swing strength, and throwing angle (Reina et al., 2018) and (Purnomo \& Yendrizal, 2020) in order to hit the Le Duo Tir target, good shooting results from good eye-hand coordination, the eyes as the main function and the hands that move the brain commands (Verhoeven \& Newell, 2016) so that motion automation will be created, the adjustment between backswing-swing-follow through will form a dynamic shooting motion pattern.

\section{CONCLUSION}

Based on the results of the study, exercises using the Le Duo Tir tool were more effective than conventional exercises to improve the shooting accuracy of NTB petanque athletes. This is shown from the results of statistical data analysis, namely for exercises using the Le Duo Tir tool, the mean value is 28.90 and for conventional exercises, the mean value is 20.40 .

\section{RECOMMENDATION}

The results of the research carried out recommend that modifications to the Le Duo Tir tool. This is done because the price of these tools is relatively expensive and difficult to obtain. Modification of the Le Duo Tir tool was carried out without changing its original function, namely as a tool that can increase shooting accuracy. In addition, by modifying the Le Duo Tir tool, increasing the number of tools so that in its application athletes can obtain a level of satisfaction. The use of the Le Duo Tir tool is recommended for petanque trainers throughout Indonesia, both from the regional and national levels to use the Le Duo Tir tool in the training program to improve the accuracy of petanque shooting.

\section{ACKNOWLEDGMENT}

Thank you for the funding provided by the Institute for Research and Community Service, University of Mandalika Education, which has funded this research through contract number 16.a/L1/PP/UNDIKMA/2021.

\section{REFERENCES}

Agustina, A. P. A. T. (2017). Hubungan Antara Tingkat Konsentrasi Terhadap Hasil Ketepatan Shooting Olahraga Petanque Pada Peserta UNESA Petanque Club. Jurnal Pendidikan Olahraga Dan Kesehatan, 5(3), 391-395. https://doi.org/https://doi.org/10.15294/active.v8i2.30467

Arieska, P. K. dan N. H. (2018). Pemilihan Teknik Sampling Berdasarkan Perhitungan Efisiensi Relatif. Jurnal Statistika, 6(2), 166-171.

Badaru, B., Hasmyati, H., Juhanis, J., \& Anwar, N. I. A. (2021). Shooting Training Model Development Of Petanque For Beginners. Halaman Olahraga Nusantara (Jurnal Ilmu Keolahragaan), 4(2), 167-179. https://doi.org/10.31851/HON.V4I2.5304

Badaru, B., Rachmat Kasmad, M., Juhanis, J., \& Anwar, N. I. (2021). Effect of Accuracy and Muscle Strength Training on the Result of Shooting Throws in Petanque. Jurnal Maenpo: Jurnal Pendidikan Jasmani Kesehatan Dan Rekreasi, 11(1), 56-66. https://doi.org/10.35194/JM.V11I1.1213

Bustomi, A. O., Hidayah, T., Okilanda, A., \& Putra, D. D. (2020). Analisis Gerak Pointing Pada Olahraga Petanque. Journal Sport Area, 5(1), 65-75. 
https://doi.org/10.25299/SPORTAREA.2020.VOL5(1).4807

Creswell, J. W. (2017). Research Design Pendekatan Metode Kualitatif Kuantitatif dan Campuran (ed. 4th). Pustaka Pelajar.

FOPI. (2019). Laporan Hasil Pertandingan Babak Kualifikasi Pekan Olahraga Nasional Cabang Olahraga Petanque Tahun 2019 di Gelang Olahraga Cendrawasih Jakarta.

Hanief, Y. N., \& Purnomo, A. M. I. (2019). Petanque: Apa saja faktor fisik penentu prestasinya? Jurnal Keolahragaan, $7(2), \quad 116-125$. https://doi.org/10.21831/jk.v7i2.26619

Hastjarjo, T. D. (2019). Rancangan Eksperimen-Kuasi. Buletin Psikologi, 27(2), 187. https://doi.org/10.22146/buletinpsikologi.38619

Hutabarat, A. L., Watimena, F. Y., \& Fitranto, N. (2017). Hubungan Konsentrasi Dan Persepsi Kinestetik Terhadap Kemampuan Shooting Pada Pemain U-11 Tahun Ragunan Soccer School. Jurnal Ilmiah Sport Coaching and Education, 1(2), 78-92. https://doi.org/10.21009/JSCE.01207

Irawan, F. A., \& Pangesti, O. P. D. A. (2020). Bokavia Sebagai Alternatif Media Pembelajaran Pada Olahraga Petanque. Media Ilmu Keolahragaan Indonesia, 10(1), 23-27. https://doi.org/10.15294/MIKI.V10I1.21368

Isnawan, M. G. (2020). KUASI-EKSPERIMEN (Sudirman (ed.); PertaMA). Nashir Al-Kutub Indonesia.

Jannah, M. (2017). Kecemasan dan Konsentrasi Pada Atlet Panahan. Jurnal Psikologi Teori Dan Terapan, 8(1), 53-60. https://doi.org/10.26740/JPTT.V8N1.P53-60

Khofifah, V., Hudah, M., \& Kusuma, B. (2021). Pengaruh Latihan Target Cone dan Ban terhadap Hasil Ketepatan Shooting Jarak 9 Meter pada Atlet Petanque Di Kabupaten Brebes. Syntax Idea, 3(4), 948-959. https://doi.org/10.36418/SYNTAXIDEA.V3I4.1120

Komarudin. (2013). Psikologi Olahraga. PT Remaja Rosdakarya.

Lubis, M. R., \& Permadi, A. G. (2020). Perbedaan Pengaruh Latihan Imagery Dan Tanpa Latihan Imagery Terhadap Peningkatan Kemampuan Shooting Game Atlet Petanque Undikma. Jurnal Ilmiah Mandala Education, 6(1), 101-106. https://doi.org/10.36312/JIME.V6I1.1114

Lubis, M. R., \& Permadi, A. G. (2021). Perbedaan Pengaruh Latihan Konsentrasi Dan Latihan Koordinasi Terhadap Peningkatan Kemampuan Shooting Game Atlet Petanque Undikma. JISIP (Jurnal Ilmu Sosial Dan Pendidikan), 5(2). https://doi.org/10.36312/JISIP.V5I2.2005

Nurfatoni, A., \& Hanief, Y. N. (2020). Petanque: dapatkah koordinasi mata tangan, fleksibilitas pergelangan tangan, fleksibilitas togok dan keseimbangan memberi sumbangan pada shooting shot on the iron? Journal of Physical Activity (JPA), 1(1), $10-20$.

Obut. (2021). The Obut Duo Tir to practise your petanque - Obut official shop. Obut.

Purnomo, A., \& Yendrizal. (2020). Effect of Hand-Eye Coordination, Concentration and Believe in the Accuracy of Shooting in Petanque. Effect of Hand-Eye Coordination, Concentration and Believe in the Accuracy of Shooting in Petanque Ari, 90-96. https://doi.org/10.2991/ASSEHR.K.200805.027

Putra, M. F., \& Kurdi, K. (2020). Petanque: Apakah Direct Instruction dapat meningkatkan kemampuan shooting dan pointing atlet? Jorpres (Jurnal Olahraga Prestasi), 16(2), 45-53. https://doi.org/10.21831/JORPRES.V16I2.30424

Reina, R., Domínguez-Díez, M., Urbán, T., \& Roldán, A. (2018). Throwing distance constraints regarding kinematics and accuracy in high-level boccia players. Science and Sports, 33(5), 299-306. https://doi.org/10.1016/j.scispo.2018.03.078

Rizal, R. M., Asmawi, M., \& Lubis, J. (2020). Petanque: Mental Training and Kinesthetic Perception of Shooting Accuracy. ACTIVE: Journal of Physical Education, Sport, Health and Recreation, 9(3), 185-191. https://doi.org/10.15294/ACTIVE.V9I3.41987 
Samsudin, N. A., \& Low, J. F. L. (2018). The effects of different focus of attention on throwing skills among autistic spectrum disorder children. Journal of Fundamental and Applied Sciences, 9(6S), 1312. https://doi.org/10.4314/jfas.v9i6s.96

Setyanto, A. E. (2013). Memperkenalkan Kembali Metode Eksperimen dalam Kajian Komunikasi. Jurnal ILMU KOMUNIKASI, 3(1), 37-48. https://doi.org/10.24002/jik.v3i1.239

Souef Gilles. (2015). The winning trajectory. Copy Media.

Sutrisna, T., Asmawi, M., \& Pelana, R. (2018). Model Latihan Keterampilan Shooting Olahraga Petanque Untuk Pemula. JURNAL SEGAR, 7(1), 46-53. https://doi.org/10.21009/SEGAR/0701.05

Verhoeven, F. M., \& Newell, K. M. (2016). Coordination and control of posture and ball release in basketball free-throw shooting. Human Movement Science, 49, 216-224. https://doi.org/10.1016/j.humov.2016.07.007

Wahyudhi, A. S. B. S. E., Ismail, M., \& Arfah, M. (2021). Koordinasi Mata Tangan, Kekuatan Otot Lengan dan Kelentukan Pergelangan Tangan terhadap Keterampilan Shooting Atlet Petanque. SPORTIVE: Journal Of Physical Education, Sport and Recreation, 5(1), 1-8. https://doi.org/10.26858/SPORTIVE.V5I1.19169

Yusuf, A. M. (2017). Metode Penelitian Kuantitatif, kualitatif, \& Penelitian Gabungan. In Kencana (Vol. 4, Issue 3). Kencana. 